\title{
It's Not about Race: Good Wars, Bad Wars, and the Origins of Kant's Anti-Colonialism
}

\author{
INÉS VALDEZ Ohio State University
}

\begin{abstract}
7 his article offers a new interpretation of Kant's cosmopolitanism and his anti-colonialism in Toward Perpetual Peace. Kant's changing position has been the subject of extensive debates that have, however, not recognized the central place of colonialism in the political, economic, and military debates in Europe in Kant's writings. Based on historical evidence not previously considered alongside Perpetual Peace, I suggest that Kant's leading concern at the time of writing is the negative effect of European expansionism and intra-European rivalry over colonial possessions on the possibility of peace in Europe. Because of the lack of affinity between colonial conflict and his philosophy of history, Kant must adjust his concept of antagonism to distinguish between war between particular dyads, in particular spaces, and with particular non-state actors. I examine the implications of this argument for Kant's system of Right and conclude that his anti-colonialism co-exists with hierarchical views of race.
\end{abstract}

$\mathbf{I}$ mmanuel Kant's Toward Perpetual Peace (from now on Perpetual Peace), written in 1795, is one of his most read and debated texts. ${ }^{1}$ Despite the abundant literature on this essay, disagreement remains

Inés Valdez is Assistant Professor, The Ohio State University, 154 N. Oval Mall, Columbus, OH 43210. In the academic year 20172018, she will be Laurance S. Rockefeller Visiting Faculty Fellow at the University Center for Human Values, Princeton University, 304 Louis Marx Hall, Princeton, NJ 08544 (inevaldez@gmail.com).

I'm indebted to Jada Earl, Kasey Powers, Elvis Saldias Villarroel, and Robin Smith for excellent research assistance on this project. For comments and feedback, I would like to thank Ishan Ashutosh, Craig Borowiak, Yvonne Chiu, Lisa Ellis, Anna Jurkevics, Katherine Marino, Lavender McKittrick-Sweitzer, Dirk Moses, Inder Marwah, Ben McKean, Sankar Muthu, Michael Neblo, Tejas Parasher, Jennifer Pitts, Alyson Price, Philipp Rehm, Hope Sample, Amy Shuster, Alex Thompson, Srdjan Vucetic, Joel Wainwright, Timothy Waligore, Alex Wendt, Peng Yu, seminar audiences at Ohio State University, Saint Louis University, University of British Columbia, University of Chicago, University of Illinois at Urbana-Champaign, University of Indiana at Bloomington, and the meetings of the American Political Science Association, Association for Political Theory, and Midwest Political Science Association, and, especially, APSR editor Leigh Jenco and referees.

Received: May 31, 2016; revised: January 20, 2017; accepted: May 12, 2017. First published online: July 10, 2017.

${ }^{1}$ In this article, I use the following abbreviations of Kant's works, in alphabetical order: $A P P V$ : "Anthropology from a Pragmatic Point of View" in (2007) Anthropology, History, and Education, ed. G. Zöller and R. B. Louden (Cambridge: Cambridge University Press); CoB: "Conjectures on the Beginning of Human History;" in (1991) Kant: Political Writings, ed. H. S. Reiss (Cambridge: Cambridge University Press); CoF: "The Conflict of the Faculties," in (1996) Religion and Rational Theology, ed. A. Wood and G. di Giovanni (New York: Cambridge University Press); CoJ: Critique of Judgment, (1987) (Indianapolis: Hacket Publishing Company); DHR: "Of the Different Human Races," in (2013) Kant and the Concept of Race, ed. J. M. Mikkelsen (Albany: State University of New York Press); DPP: "Drafts for Perpetual Peace," in (2016) Lectures and Drafts on Political Philosophy, ed. F. Rauscher (Cambridge: Cambridge University Press); IUH: "Idea for a Universal History with a Cosmopolitan Purpose," in Kant: Political Writings; LCFS: "Letter to Carl Friedrich Stäudlin. December 4, 1794;" LCS: "Letter to Carl Spener. March 22, 1793;" LFTG: "Letter to François Théodore de la Garde. November 24, 1794," all in (1999) Correspondence, ed. A. Zweig (Cambridge: Cambridge University Press); MoM: "The Metaphysics of Morals," OCS: "On the Common Saying: This Might be True in Theory but It Is of No Use in Practice," both in (1996) Practical Philosophy, ed. M. J. Gregor (Cambridge: Cambridge University Press); RJGH: "Review of J.G. Herder's Ideas for the Philosophy of History of Humanity," about the grounds of his anti-colonialism, which he formulates systematically for the first time in Perpetual Peace. This article offers a novel contextual interpretation of Kant's anti-colonialism by highlighting the importance of the political and economic context, the particular character of the colonialism he opposed, and his concern with intra-European equilibrium.

Existing contributions offer enlightening contextual accounts of Perpetual Peace but they either focus on its internal intellectual context, that is, his broader writings (Bernasconi 2003, 2011; Hedrick 2008; Kleingeld 2007, 2014b) or its external intellectual context, that is, the dialogues he established with contemporaries (Cavallar 2014; Kleingeld 2012; Maliks 2014). But these approaches miss the connections between Kant's thought and the social and political world (Moyn 2016), which this article considers. In particular, at the time, colonialism and colonial conflict were central to $\mathrm{Eu}-$ rope's political economy and its military strategy. Despite this, Kant scholars have analyzed his comments on colonialism in the third article of Perpetual Peace without connecting them to his claims on republicanism and European international relations in the first and second articles of this essay. Scholars' narrow reading of 18th century European politics (certainly narrower than Kant's own) has led interpreters away from a politically careful reading of Kant's comments on colonialism in Perpetual Peace or the meaning of concepts in Kant's system, including colonialism, trade, and antagonism. The proposed examination - I argue - is necessary to go beyond what Kant was saying and understand what Kant was doing. ${ }^{2}$

in Anthropology, History, and Education; TPP: "Toward Perpetual Peace," in Practical Philosophy; and UTP: "On the Use of Teleological Principles in Philosophy," in (2001) Race, ed. R. Bernasconi (Malden: Blackwell Publishers).

${ }^{2}$ In this article, I highlight how attending to the political context and European bellicose entanglements that surrounded Kant's writing suggests a novel interpretation of his article on cosmopolitanism. While I support my argument with an analysis of the Drafts for Perpetual Peace and selected pieces of Kant's correspondence, the more precise question of what Kant knew and made of the context I describe remains as an avenue for further research. 
My argument is twofold. First, Kant's anticolonialism-as expressed in Perpetual Peaceremains Eurocentric and partly motivated by a concern with the effects of three features of colonial conflict (rather than colonialism) on the prospects of republicanism and peace in Europe: (i) European expansionism, (ii) intra-European colonial rivalry, and (iii) the cruel/uncivilized practices characteristic of colonial conflict. Second, Perpetual Peace can be seen as a veiled attack on Britain, France's rival and the world leader in terms of naval power, the slave trade, and colonial possessions.

To develop these points the next section introduces the debate on Kant and colonialism and the related discussion on race. Next, I examine the context of writing by exploring the history of colonial sites that Kant mentions by name in Perpetual Peace, his correspondence, and other contemporaneous essays. I argue that his primary concern was Britain's expansionism and how it hindered republics from developing and fueling progress toward peace. The next section explains how the historical reconstruction depends on a particular interpretation of Kant's philosophy of history and the place of conflict within it, which changes after he examines colonial conflict closely. I then examine how Kant's transformed notion of teleology allows him to differentiate between war among European states (which indirectly leads to peace); intra-European conflict in and about the colonies (which multiplies conflict and endangers republics); and conflict between European countries and non-European peoples, characterized by cruelty and evil (which is debasing for Europeans). Finally, I consider my reading vis-à-vis, on the one hand, Kant's system of Right, which he develops more fully in the The Metaphysics of Morals, and, on the other hand, his racial hierarchy. In the conclusion, I discuss the need to problematize and move beyond the blindspots of Kantian cosmopolitanism in contemporary scholarship.

In sum, Kant's anti-colonial cosmopolitanism, despite its grounding on Right, implies a retreat from the world that coexists with hierarchical views of race and civilization. My interpretation suggests that Kant's critique of colonial conflict, which appears in an essay concerned with republicanism in Europe and European peace, is at least partially devoted to advance republicanism in Europe (domestic Right) and peace in the European continent (international Right).

\section{COLONIALISM, RACE, AND EUROPE}

The "Definitive Articles" of Perpetual Peace introduce Kant's system of Right, composed of domestic, international, and cosmopolitan Right. Kant argues that republicanism is the ideal system of domestic government and traces an expected progression of European states toward peace through the leadership of republics and the formation of a voluntary federation of states. Regarding republics, he argues that "the civil consti- tution of every state shall be republican," a regime founded on the "freedom of the members of a society ... the dependence of all upon a single common legislation ... and their equality" (322, 8:249-350). The second definitive article establishes that "[t]he right of nations shall be based on a federalism of free states," a practical end because an "enlightened people can form itself into a republic," which, being naturally peaceful, provides a focal point for other states "to attach themselves to it" and gradually extend further and further" $(325,327,8: 354,356)$. In contrast to previous accounts of cosmopolitanism in Idea for a Universal History with a Cosmopolitan Purpose (Idea, from now on) and the Critique of Judgment, where the cosmopolitan condition was achieved through the federation of states, in Perpetual Peace, cosmopolitanism appears as a separate realm regulating other types of relationships (Kleingeld 2014a, 68-71), notably European actions in non-European regions.

Kant had dealt with non-Europeans in his anthropology and geography, where he classified them as racially inferior to European whites. Scholars have noted two stages in Kant's racial theories: an early and less systematic stage, and the later stage-developed in the 1780 s - when race takes a teleological character and is connected to Kant's critical philosophy (Larrimore 2008, 356; Bernasconi 2011; Larrimore 1999). In particular, Kant tied racial difference to seeds that were triggered (not caused) by climate and slowly unfolded but eventually became permanent racial traits (Larrimore $2008,344)$ resulting in a hierarchy with whites at the top and Native Americans at the bottom. Regarding the latter he argued in 1788 that "their natural disposition has not yet reached a complete fitness for any one climate ... too weak for hard labor, too indifferent for diligence, and unfit for any culture, still stands - despite the proximity of example and ample encouragementfar below the Negro himself," who otherwise holds the lowest rung in the racial ladder (UTP, 48, 8:175-176). In his 1780 s lectures, Kant asserts that only the white race contains "all incentives and talents" and even the "Hindus" who can be educated (and are thus superior to "Negroes") can be trained in the arts but not in abstract concepts (15:877-8).

Kant pairs these assertions with uncritical discussions of Europeans' activities overseas, remarking upon the uses that the different races should be put to given their natural predispositions $(D H R, 333$, 2:438n). As late as 1792, Kant cites approvingly David Hume's statement that Africans have no claim to equality and in the same lectures he contends that no freed Negro has distinguished himself with any skill (which is conducive to culture, according to Kant's Critique of Judgment) (Bernasconi 2011; Clewis 2015; Kleingeld 2014b). Moreover, in his early 1780s Lectures on Physical Geography (Doenhoff) (cited by Kleingeld 2014b, 46, 66) Kant argued that peoples from Hindustan would be "much happier" if "ruled by a European sovereign" and, in 1785, noted that unless visited by "more civilized nations," Tahitians 
would live in peaceful indolence forever $(R J G H, 142$, $8: 65){ }^{3}$

In 1795, however, Kant publishes a critique of European powers' behavior in non-European regions (Kleingeld 2014b; Niesen 2007; Valdez 2012). The passages contain explicit and graphic descriptions of the violence performed by Europeans, contrasting the right to hospitality to the horrifying "inhospitable behavior of civilized, especially commercial states in our part of the world, the injustice they show in visiting foreign lands and peoples (... tantamount to conquering them)" (TPP, 329, 8:358). He continues by highlighting atrocities in particular areas including "America, the negro countries, the Spice Islands, [and] the Cape" all of which were considered ownerless, "since [Europeans] counted the inhabitants as nothing" (TPP, 329, 8:358). Kant then notes how these explorations spur internal conflict, particularly in the East Indies, where foreign soldiers arrived with the excuse of "set[ting] up trading posts" but ended up oppressing the inhabitants and inciting Indian states to "widespread wars, famine, rebellions, treachery, and the whole litany of evils that oppress the human race" (TPP, 329, 8:358-359). After praising Japan's and China's restrictive policies, Kant notes that the worst (or best, from the moral standpoint) aspect of this violence is that it is not profitable for commercial states, whose trading companies are on the verge of collapse. He offers the example of European actions in the Sugar Islands - site of the "cruelest and most calculated slavery" - that yield no profit but serve the intermediate and not very commendable purpose of training sailors to carry on wars in Europe (TPP, 330, 8:359).

How do we reconcile Kant's theory of racial hierarchy and his approving remarks of civilized rule before 1795 with the critique in Perpetual Peace? The connection between Kant's racial thinking and the status of colonialism in his system is contested in existing literature. For example, Anthony Pagden notes that Kant's writings do not engage consistently with "colonies as such," and what he says is often "confused and contradictory" $(2014,19)$. Other scholars argue that colonialism (and hierarchy more broadly) is necessary in the trajectory of progress Kant envisions, even if morally objectionable (McCarthy 2009, 171; Tully 2008, 146-7). Yet others claim that Kant was simply unconcerned with colonialism, given that he considered non-whites "meaningless in the grand teleological scheme of things" (Larrimore 1999). In a recent exchange, however, Pauline Kleingeld (2007; 2014b) and Robert Bernasconi $(2001 ; 2011)$ have argued that Kant's racial views led him to uphold colonialism on both paternalist and instrumentalist grounds. This view interprets Perpetual Peace as a change of heart, which Kleingeld attributes to unrecorded shifts toward racial egalitarianism, and Bernasconi sees as compatiblethough in tension - with Kant's universalism.

\footnotetext{
${ }^{3}$ References to external rule as leading to improvement, it must be noted, stand uneasily with Kant's own account of racial difference as permanent.
}

This debate focuses on the following questions: does the moral condemnation of colonialism in Perpetual Peace depart from previous statements? And, if so, does it follow from a shift in his thinking on race or not? In contrast, I argue below that the impulse behind Kant's inauguration of a cosmopolitan realm and his critique of colonialism should be understood along Perpetual Peace's overall argument about republics, an international federation, and their connection to peace. This explanation is internally coherent - vis-àvis other arguments in the same essay-and externally coherent - vis-à-vis the political and economic context that has not been considered before, and thus interpretatively firmer than connecting this shift to other areas of his thought less soundly documented. This argument suggests that Kant became concerned about colonial conflict when he realized that, rather than necessary, it was detrimental for progress toward peace. Moreover, my argument shows that claims about the hypothetical benefits of civilized rule in his earlier writings - made in the context of his discussion of race hierarchy-are qualitatively different than the ones in Perpetual Peace, which engage in detail with the far from civilized reality of colonialism and are explicitly tied to political debates and priorities in Europe. Part of this condemnation explicitly targets the injustice of these actions, which means that we cannot assert Kant's complete moral disregard for non-Europeans and an acceptance of the violent practices underlying European imperialism. As I show below, however, concern for non-Europeans and anti-colonialism are compatible with persistent hierarchical beliefs about race and civilization on Kant's part.

\section{WHAT COLONIALISM?}

To understand Kant's position in 1795 we need to, on the one hand, explore the connection-if any-that exists between his earlier statements on colonialism, made in the context of his discussion about race, and his 1795 condemnation of colonialism, and, on the other hand, be cautious about interpreting his statements as being simply about the rightfulness of dyadic relations between colonizer and colonized. This requires that we assess the critique of the violence of Europeans' actions in the non-European world on its own terms, before settling on their particular meaning and their place in Kant's overall system.

Existing literature on this topic has so far examined Kant's critique in light of conceptual histories of the notion of "colony" (Pagden 2014); as connected to evolutions of his thought on race (Kleingeld 2014b); associated with his growing appreciation of cultural diversity (Muthu 2014), or explained through Kant's discussion of international law (Niesen 2014, 173-7; Ripstein 2014, 146). Others have noted that Kant's changing notion of teleology explains both his reformed racial thought and his shift against colonialism (Storey 2015; Ypi 2014a). None of these scholars, however, scrutinizes the kind of colonial conflict that Perpetual Peace addresses, despite the fact that Kant explicitly mentions six 
non-European locations in the article on cosmopolitanism. Existing scholarship also does not ask what purpose the critique of colonialism serves in an essay motivated by the Revolutionary Wars, which Prussia fought until 1795, when it signed the Peace of Basle, which removed it from the confrontation for about a decade. ${ }^{4}$ My interpretation concentrates on the historical background of the non-European locales mentioned by Kant in his article on cosmopolitanism and shows that Kant's analysis of colonial conflict is tightly integrated with the discussion on republicanism and European peace that occupies the rest of Perpetual Peace.

The Cosmopolitan section of Perpetual Peace references the following geographic areas: the Cape (Cape of Good Hope, South Africa), the Spice Islands (Maluku Islands, Indonesia), the Sugar Islands (Caribbean Islands), the East Indies (South and South East Asia), the "negro countries" (West Africa), and America (North America). These locales were not simply sites where a European aggressor conquered and dominated natives but places that witnessed intense strife involving two or more European powers in ways that were directly or indirectly connected to the American and French revolutions (Figure 1 provides a timeline of major events and Kant's writings).

If we organize the historical analysis around the American and French revolutionary wars, we can see that they resulted in important European infighting in the colonies (among European states, through trading companies, or native allies) - especially in the six geographic areas explicitly mentioned in Perpetual Peace. During the American Revolution, France's support for the colonies and Holland's neutrality led to wars contemporary to the Revolutionary War: the AngloFrench War (1775-1783) and the Fourth Anglo-Dutch War (1780-1784). The fighting in these wars was not restricted to continental Europe or North America's surroundings: clashes between France and Britain took place in South East Asia, where France still had holdings (Malleson 2010). In particular, the Second Mysore War was fought between the British East India Company and the Kingdom of Mysore, a French ally (Pradeep 2011, 29). Britain also attacked outposts of the Dutch East India Company, which lost Negapatam (Southern India), Ceylon and other outposts of the Indian subcontinent, in addition to the Maluku islands (Edler 1911, 245-6; Tarling 1958, 182). This led to the decline of the Dutch East India Company company and its West Indian counterpart, which had been losing its West African slave trading posts to France and Britain during the 18th century (Furnivall 2010, 50-1; Rawley and Behrendt 2005, 78-9).

Dominance in the slave trade was tightly connected to the power of the naval and merchant fleets available to European powers (Rawley and Behrendt 2005, 967). This does not escape Kant, who in the Drafts for Perpetual Peace (from now on Drafts) links the slave

\footnotetext{
${ }^{4}$ Scholars mention the Peace of Basle as the motivating event for the essay, but do not interrogate its connection with Kant's discussion of colonial conflict (Kleingeld 2012; Wood 1998).
}

trade, naval power, and the capacity to fight more and more violent wars $(222,23: 174)$. Because of the triangular structure of trade, ${ }^{5}$ the slave trade was tightly connected to the trade in sugar, which was a prized commodity. Contemporaries to Kant, like the Abbé Raynal, took "the labors of the colonists of the longscorned islands [the Caribbean]" to "double perhaps triple the activity of ... Europe" and the principal cause of the "rapid movement which stirs the universe" (Shapiro 2008, 72). ${ }^{6}$ Trade restrictions imposed on Britain's North American colony, possibly devoted to undermining France's West Indies vis-à-vis British ones, led to North American discontent for the lack of access to trade with the thriving French possessions. In response, Britain partially legalized trade with the French West Indies, but contraband continued to thrive and disputes remained, becoming subsidiary causes of the American Revolutionary War. France's interest in protecting its West Indies possessions, in turn, was a prime reason for supporting Americans (Rawley and Behrendt 2005, 104-5; Egnal and Ernst 1972), with significant fighting between Britain and France taking place in the Caribbean (see Figure 1). In addition to these clashes, several slave trading posts in West Africa changed hands between France and Britain during the Anglo-French War (France took Saint Louis, in present-day Senegal, and Fort James, in Gambia; while Britain took Gorée, in Senegal) (Rawley and Behrendt 2005, 105).

This reconstruction suggests that Kant's goal in naming those sites in Perpetual Peace is to highlight the harms brought about by Britain's naval dominance, its refusal to let go of its North American colonies, and the vast spatial reach of its warfare. European struggles were amplified into non-European space and by enlisting trading companies and non-European manpower for war. This imperiled European peace and the development of the American Republic. Importantly, many of the rivalries around commercial interests and trading spots in the colonial locales analyzed above were still playing out during the French Revolutionary Wars (i.e., the immediate context of Kant's writing), which I examine next. This analysis confirms that Kant's concern with intra-European conflict, British expansionism, and the fate of republics was a prominent impulse for writing the third article.

The War of the First Coalition (1792-1802) was the first part of the Revolutionary Wars, in which allied Europeans fought Republican France. The Peace of Basle - which famously motivates Kant to write Perpetual Peace-brought a temporary pause to this war and was signed by Prussia and Spain in 1795, the same

\footnotetext{
${ }^{5}$ During the 18th century, the slave trade relied on the use of merchant ships for transporting-subsequently-European manufactures, slaves, and sugar. Intra-European rivalries were commonly about trade, control of strategic areas in West Africa and the West Indies, the regulation of access to slave markets (e.g., the "asiento," the Spanish's crown authorization to transport slaves to Spanish America, was particularly coveted), and sugar production (Rawley and Behrendt 2005, 101).

${ }^{6}$ In 1795, France and Britain were the greatest sugar producers and exporters in the world (Mintz 1985, 35).
} 


\section{FIGURE 1. Timeline of Kant's Works and Historical Events}

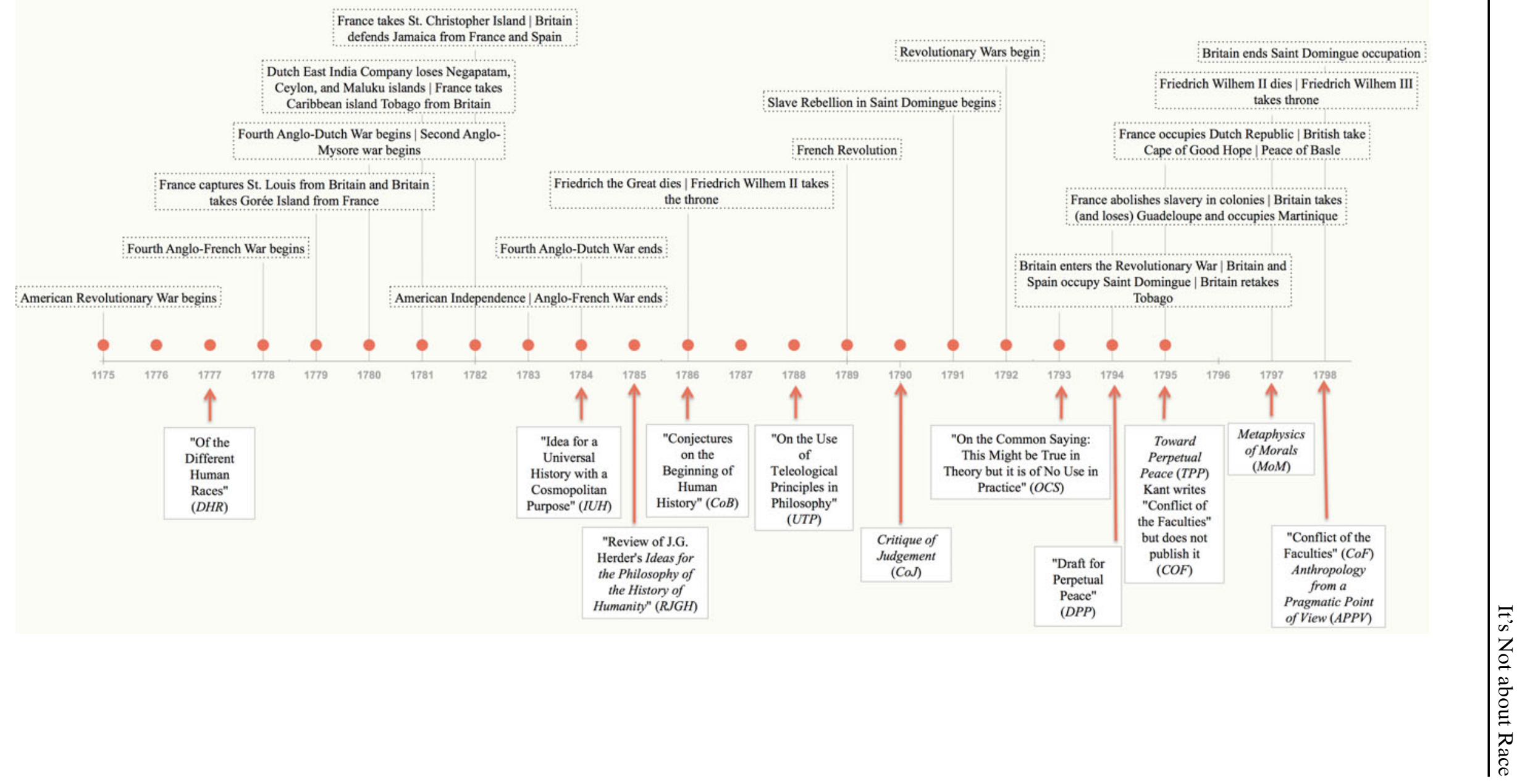


year when France and Holland signed the Treaty of The Hague after Holland's defeat (Blanning 1996, 135; Dubois and Garrigus 2006, 30). Soon after the outbreak of the war, Spain and Britain invaded French Saint Domingue, where conflict had been ongoing since the 1791 slave rebellion. This rebellion disrupted the sugar trade, benefitting Britain and Spain-also sugar producers-and gave way to feuds between France and the United States (Dubois and Garrigus 2006, 30). Britain and Spain - while committed to slavery in their possessions-supported rebelling slaves in Saint Domingue (Geggus 1982). The 1795 peace treaty transferred the Spanish territory back to France, while the British capitulated in 1798. Additionally, Britain retook Tobago in 1793-after 12 years of French rule - and invaded Martinique in 1794 (Laurence 1995, 7; Morgan 2007, 48). In February 1794, the island of Guadeloupe was invaded by the British (in coalition with anti-abolition French planters), only to be retaken by France in December (Morgan 2007, 48).

Conflict in West Africa had abated by this period. France never became self-sufficient in transporting slaves to its Caribbean colonies and Britain became dominant in the Atlantic slave trade, transporting over $50 \%$ of slaves between 1791 and abolition (Rawley and Behrendt 2005). Finally, Kant's reference to the Cape is aligned with the other examples. Given its strategic location on the route to India, Adam Smith deemed its discovery one of the greatest events of the era (Bell 2016, 3n) and it was at the center of Anglo-French maritime rivalry in the late 18th century (Turner 1966). In 1795, in particular, the Cape was a front in the Revolutionary Wars, when Britain took it over from the Dutch in retaliation for France's occupation of the Dutch Republic (Palmer 1954, 22). Interestingly, the example of the Cape appears only in the published version of Perpetual Peace, unlike the others, featured already in the Drafts, which Kant started writing in 1794. This is perhaps because Kant decided to add this case only after hearing of the events in January 1795.

In sum, the non-European sites that Kant mentions in his essays are quite diverse: West Africa, site of European slave trading posts without territorial control; the Caribbean, prime destination of slaves demanded by European planters who produced one of Europe's most prized commodities; America, likely its northern part, characterized by settler practices and the exploitation of natives; the Cape, strategic port on the way to India; India, site of struggle between trading companies, which controlled territory in alliance with local rulers; and the Spice Islands, site of competition among Europeans over access to spices. This variegated set of examples does not seem to amount to a coherent point about colonialism, unless the point is about $\mathrm{Eu}-$ ropean states competing viciously among each other for colonial sites in ways connected to trade and intraEuropean wars.

This reading takes Kant's claims on colonialism to be an integral part of Perpetual Peace, rather than assuming they contain his self-standing critique of colonialism, and reveals Kant's frustration with expansionism, particularly on the part of Britain, which appears as the aggressor in a significant number of the examples he offers and is the dominant world power at the time. He also appears to grapple with the character of colonial conflict and its effects on republicanism and peacewhich occupy the rest of the essay-rather than with the dyadic encounter between colonizer and colonized. There is little continuity between this focus and the arguments in previous examinations of colonialismconcerned with non-Europeans as subjects that would benefit from external (civilized) rule, given their defective capacity for self-government or passivity.

Kant's claims in the cosmopolitan section of Perpetual Peace are also different from later discussions outlawing the establishment of colonies and bondage after war between states, located in the section on international Right of the Metaphysics of Morals, applicable to interactions among European states. Contra interpretations of Kant's anti-colonialism as resulting from international Right and-in particular-the regulation of war (Niesen 2014; Pagden 2014; Ripstein 2014), Kant consistently does not include any treatment of conflict with non-Europeans in the sections on international Right (in Perpetual Peace and the Metaphysics of Morals). This exclusion was not simply about the political status of these peoples, given that Kant explicitly considers some non-Western peoples to be states, that is, he refers to Indian "states" [Staaten] and to China as a "great empire" [großes Reich] in Perpetual Peace (329-330, 8:359-360). He arguably would have thought of Japan equivalently, given the long-standing political order in that region, which was "fully capable of resisting [Europeans'] demands" (Clulow 2014, 378 ), a feature that Kant praises in his essay. Thus, at least in Perpetual Peace, Kant categorizes interactions with both non-Western non-states and non-Western states as part of the cosmopolitan realm, though the latter examples disappear from his discussion on cosmopolitanism in The Metaphysics of Morals. In this work, Kant also discusses interactions with non-state actors in the section on Private Right (MoM 417, 6:266) in order to address arguments of legitimate property used to justify colonial expansionism (Williams 2014).

\section{War, Britain, and the Context of Writing}

The previous section suggests that Kant's concern was with the spatial extension of intra-European conflict beyond Europe and into the colonies, and with the nonconventional character of this conflict. The dominant colonial power in Kant's time was Britain, and both of the wars examined had Britain at their center. If this was the case, why didn't Kant address the question of Britain's expansionism and belligerence more directly? In this section, I put forward complementary evidence that suggests that Kant may not have been able to criticize Britain directly. While scholars have noted that Kant's writings on religion were repeatedly censored during the reign of King Friedrich Wilhelm II (Wood 1996a, xv-xxiv), less has been said about how the war also made Kant hesitate to speak out openly about warfare and international politics. But this was clearly the case. For example, in 1793, he declined to 
re-publish his essay Idea for a Universal History with an addenda about "current affairs" because "the powerful of this world are in a drunken fit ... one must strongly advise a pygmy who values his skin to stay out of their fight" ( $L C S, 456,11: 417)$.

Kant's hesitation to write about the war was likely due to the participation of Prussia in the War of the First Coalition against France. Writing on republicanism or criticizing European powers' behavior would have likely upset the Prussian monarchy, as he confirms in another missive: "the hand of the censor lies heavily" not only on religion but also on "public law [Staatsrecht] and international law [Völkerrecht])" (LFTG, 489, 11:531). In 1794, Kant holds off on publishing the first part of Conflict of the Faculties (from now on Conflict), which he wrote for the Göttingische Bibliothek der neuesten theologischen Literatur but ultimately declined to publish. The journal, based at the University of Göttingen, in Hanover, a personal union with Great Britain, would shelter Kant from Prussian censorship ("the orthodox George III" would be sufficiently esteemed by the "equally orthodox" Friedrich Wilhelm II so that he would be shielded from the "hyper orthodox ... in our locality" (LCFS, 491, 11:533)). This suggests, on the one hand, that there was a special relationship between Prussia and Britain so that the sponsorship of a Hanoverian university would assuage the censors. On the other hand, it suggests that Kant's critiques of Britain would be particularly scrutinized.

Kant's critique of Britain would have hit close to home because of the deep political and familial connections between the Houses of Hanover and Hohenzollern, which ruled Britain and Prussia. Duke Karl Wilhelm Ferdinand of Brunswick-Wolfenbüttel (from the electorate of Hanover, then a personal union with England) was married to George III's sister, Princess Augusta, and commanded the allied troops of Austria and Prussia in the War of the First Coalition (Brown 2003; Krimmer 2008). He also lent his name to the 1792 Manifesto $^{7}$ that threatened the "complete ruin" of Paris if the French monarchs suffered any violence at the hands of their people (Fremont-Barnes 2001, 25). The future King Louis Philippe claimed that this missive "inspired more enthusiasm in France for the defense of the fatherland than the patriotic appeals of the National Assembly and the revolutionary societies put together" (cited in Blanning 1996, 72).

This was the charged climate that surrounded Kant, which may explain that Perpetual Peace was published during the armistice, which kept Prussia out of the war until 1806 and allowed intellectuals to consider the question of war (Krimmer 2008, 47). Yet Britain remained at war and was belligerent in French-controlled areas such as the Cape of Good Hope and Saint Domingue in 1795. Interpretively, this context suggests that Kant may have been reluctant to explicitly criticize Britain, despite the fact that the status of Britain as the major slave trader, naval power, and France's

\footnotetext{
${ }^{7}$ Which was in fact authored by French émigrés (Blanning 1996, 101).
}

archrival would have warranted it. Despite Kant's selfcensorship, incorporating the historical context suggests that he was concerned about Britain's expansionism, which other works written around the same time confirm. For example, Kant does not publish Conflict until 1798-after the death of Friedrich Wilhelm II and the end of the War of the First Coalition. This is unsurprising, given that the second part of this essay claims the British monarchy is "unlimited" because "everyone knows perfectly well that the monarch's influence ... is ... so certain that nothing is resolved by the Houses except what he wills and purposes through his minister" (305-306, 7:90). However, we know Kant was working on this part in 1795 (Wood 1996b, 276), which suggests these questions were in Kant's mind when he wrote Perpetual Peace.

While the critique is explicit in Conflict, it is possible that Kant's comment about the Sugar Islands as a "stronghold of the cruelest and most calculated slavery" (TPP, 330, 8:359) was also directed against Britain, given that, by 1795, France had abolished slavery in the colonies. ${ }^{8}$ Britain was also the only belligerent party left in the area, after Spain returned its portion of Saint Domingue (Whitaker 1936). More specific language also appears in Kant's critique of Europe in the Drafts, where he singles out for critique the "coastal people of the seas" [Küstenvölker] among the civilized states $(221,23: 173)$.

Britain's expansionism threatened balanced European war, which Kant valued not because it led to a traditional balance of power, which he considered a "mere fantasy," but because of the "lively competition" or "productive resistance" that-along with political practices and institutions - could lead to an enduring and lawlike peaceful balance (OCS, TPP; Muthu 2014). ${ }^{9}$ This finding led Kant to a more finegrained consideration of the role of antagonism in his philosophy of history. This reconsideration, however, depended on a shift in Kant's teleology that allowed for the examination and critique of man's free action in interaction with the laws governing nature, with the goal of making possible the realization of the highest end.

\section{ANTAGONISM AND EQUILIBRIUM}

The stark critique of conflict that appears in Perpetual Peace seems to contradict the role that antagonism and war had in Kant's philosophy of history, but this is because Kant's conception of antagonism shifts between Idea and Perpetual Peace to accommodate colonial conflict. This reformulation was enabled by Kant's new understanding of teleology, presented in the Critique of Judgment.

\footnotetext{
${ }^{8}$ Following the request in February 1794 by three deputies from Saint Domingue (one black, one mulatto, and one white) and against the strong opposition of the French colonists of the island (Gauthier 2014, 273-80).

${ }^{9}$ The distinction between the notion of equilibrium, or the "right to equilibrium" [Recht des Gleichgewichts] and "balance of power" [Balance der Mächte] in Kant is sometimes lost in English editions which wrongly translate the former as balance of power $(M o M, 484$, 6:346; OCS, 309, 8:312).
} 
Antagonism results from men's asocial sociability [ungesellige Geselligkeit], which Kant defines in Idea as "[the tendency] to come together in society, coupled" with continual resistance that "constantly threatens to break this society up" (44, 8:21). Asocial resistance transforms men's "primitive natural capacity for moral discrimination into definite practical principles" and compels them to come together under a civil constitution. The same logic applies to states in the state of nature, whose "natural capacities" cannot be developed due to the expenditure of commonwealths' resources on armaments, war depredations, and the imperative of war readiness.

These evils, however, "still have a beneficial effect" (IUH, 49, 8:25-26). Wars, military preparations and the distress that follows them are "means by which nature drives nations" to prepare to take a step that reason would have dictated without so many "sad experiences:" to abandon a "lawless state of savagery and enter ... a federation of peoples" where every state can derive its security and rights from a "united power and the law-governed decisions of a united will" (IUH, 47, 8:24).Thus, the path towards a federation need not be dictated by reason because nature employs the antagonism of men and of states as means to "calm and security" (IUH, 47, 8:24). The teleology of nature in Idea operates irrespective of men's intentions: the "intention of nature" fuels wars and destroys some states, dismembers others, and results in revolutions that will eventually result in a peaceful state of affairs (IUH, 48, 8:24-25). Certain civil arrangements, moreover, facilitate efforts on the part of commonwealths to educate their citizens and to allow them to mature morally. This process is neither intentional nor random but guided by the "wisdom of nature" and need not lead to a "lapse into inactivity" but to a government of the actions and counter-actions through a principle of equality (IUH, 49-51, 8:25-26).

In Idea's account of antagonism, Europe is the site of progress, and wars and commerce occur among European states. ${ }^{10}$ The strong language indicates that Kant acknowledges the violent propensities of individuals and states but trusts these dimensions to awaken the natural capabilities of men and-through the mere exhaustion and learning from the destructiveness of these events-encourage the establishment of a common constitution. These natural capacities, or germs [Keime] to be developed, are, according to his racial theory, differently distributed among different races, with only the European race being able to fully develop morally. ${ }^{11}$ In sum, Kant's idea of cosmopolitan

\footnotetext{
${ }^{10}$ Only in one passage does Kant mention other regions, when he argues that knowledge about them confirms the improvement of Europe's political constitutions, which "will probably legislate eventually for all other continents" (IUH, 52, 8:29). Kant is thus thinking about non-European regions as eventually somehow subsumed under the European imperial states that will join in a federation and form a cosmopolitan whole. This is consistent with Kant's assessment of non-white races as lacking (in different degrees) politically relevant capacities of self-government, magistrature, freedom, and virtue (Kleingeld 2014b, 46).

${ }^{11}$ While scholars have argued that Kant's "impure" ethics play a role in his definition of moral nature and results in differential affinity
}

progress in Idea is Eurocentric, hierarchical, and potentially imperial, even if not particularly concerned with the specificities of the empires taking shape as he was writing.

A decade later, Perpetual Peace opens by warning readers about destructive war resulting in "peace of graveyards" (317, 8:343). Kant offers a more critical view of war and trade and enacts specific regulations limiting and regulating violence, rather than expecting it to lead indirectly to peace, as in Idea. Relations between Europe and the rest of the world, and between state and non-state actors (which had not concerned him in 1784), are now regulated by a separate cosmopolitan sphere. Despite these qualifications, the idea of war as beneficial does not disappear. Certain forms of conflict are still conducive to a civil constitution, but certain techniques of war, certain dyads, and wars in particular spaces are unconditionally condemned. The criteria by which antagonism is evaluated is connected to the question of equilibrium, a notion already present in Idea. Antagonism is conducive to moral progress because it "compel[s] our species to discover a law of equilibrium to regulate the essentially healthy hostility which prevails among the states and is produced by their freedom." The cosmopolitan whole envisioned in Idea "reinforce[s] this law by introducing a system of united power [and] ... political security" thatthrough equality-governs the actions and counteractions so that states do not "destroy one another" (49, 8:26).

Equilibrium remains important in 1793, when he suggests that "it is not in the nature of the human being to relinquish his power by choice," but reason relies on the evil that arises from the opposition of inclinations to one another to play freely and "subjugate them all and, in place of evil" establish the selfsustainable rule of good (OCS, 308-309, 8:312). This focus is found in Perpetual Peace in the Appendix and in the "Guarantee for Perpetual Peace." In the latter, while discussing international Right, Kant contrasts healthy equilibrium and despotism. He argues that while "the separation of neighboring states independent of one another" is a condition of war (that could only be avoided by a federative union), this is better, in accordance with reason, than if these states were fused "by one [despotic] power overgrowing the rest." Here nature re-appears, and "wills it otherwise:" while differences of language and of religion bring pretexts for war, "increasing culture and the gradual approach of human beings to greater agreements in principles" leads to understanding in a state of peace that "is produced and secured ... by means of their

between particular cultures and moral ends (Louden 1999; Marwah 2012), disagreement remains about the moral implications of Kant's developmental thinking for his moral thought (Bernasconi 2003, 2011; Hill Jr. and Boxill 2001; Kleingeld 2007; Larrimore 2008; Mills 2005 , 2014). It should be noted, however, that when Kant refers to "humanity" when discussing progress, this does not imply that "whites and non-whites will equally contribute to and share in this process," as Kleingeld notes" $(2007,582 \mathrm{n})$. The whole may be progressing even if "some of them lag behind" as Kant noted in his Reflections on Anthropology (15:650; cited in Kleingeld 2007, 582n). 
equilibrium in liveliest competition" (TPP, 336, 8:367, my emphasis; see also $D P P, 225,23: 187)$. We see the indirect value of war in other portions of the "Guarantee," when Kant notes that "by war [nature] has compelled peoples" to both spread out in the world and "enter into more or less lawful relations" (TPP, 332-333, 8:363). War, he continues, "needs no special motive but seems to be engrafted onto human nature and even to hold as something noble" (334, 8:365). War, or the threat of it, also forces peoples "to submit to the constraint of public laws" given that "each people would find itself in the neighborhood of another people pressing upon it, against which it must form itself internally into a state in order to be armed as a power against it" (TPP, 335, 8:366).

The discussion of the indirectly beneficial effects of antagonism in equilibrium relies on Kant's arguments in the "Critique of Teleological Judgment," according to which the standpoint of scientific inquiry and moral conduct both rely on a conception of nature "as a realm governed by laws that make possible the realization of the ultimate object of morality" (Guyer 2005, 317 ), without conflating the two types of arguments (i.e., a step taken "toward morality" is not necessarily a "a moral step" $(T P P, 343,8: 376)) .{ }^{12}$ It is notable, however, that unlike the other definitive articles of Perpetual Peace, the cosmopolitan section addresses simultaneously questions of Right and the question of realizability - to which he devotes most of the space, likely because this is the first time he considers seriously how colonial antagonism fits within his philosophy of history. Hence, he deals with both moral judgments (what is moral conduct, what is the highest end) and reflective judgments (how are these ends achieved given the natural constraints we face). Kant makes reference to the unprofitability of colonial violence, a fact that is welcome from "the standpoint of the moral judge [moralischer Richter]" (TPP, 330, 8:359). The purpose of colonial violence, Kant claims, is "mediate and not particularly laudable," in contrast to purposeful actions that lead to moral progress. In other words, Kant notes that, first, colonial violence is morally objectionable (a determinative argument); second, we can expect that it won't persist, given the profit-seeking nature of human beings (a reflective argument); and, third, persistent conflict of this kind works against progress toward morality (a reflective argument).

This is consistent with Kant's "pragmatic anthropology," namely "the investigation of what [the human being] as a free-acting being makes of himself, or can and should make of himself" ( $A P P V, 3,7: 119)$. In this scheme, nature contributes to morality by providing the conditions for the development of the cultures of

\footnotetext{
12 Kant's shifting teleology is also the focus of Lea Ypi's and Ian Storey's effort to understand his anti-colonialism. Ypi argues that in the 1790s Kant rejects trade and accepts only rightful war as mechanisms that would result in progress (2014a, 115-6, 22-24), but I suggest a more fine-grained reconceptualization of antagonism is at stake. Storey, in turn, notes that Kant's teleological shift makes judgments about race only subjectively valid $(2015,682,6)$, but sees Kant's anti-imperialist arguments as evidence of a shift toward racial equality without, however, considering the explanation offered here.
}

skill and discipline, with the latter being particularly central to tame the "crudeness ... of our animal inclinations and prepare man for a sovereignty of reason." Judgment's role, in turn, is to identify and criticize actions that are not harmonious with the maximum development of human beings' natural predispositions and to devise institutions that can regulate our freedom (CoJ, 319-321, 5:431-433; Ypi 2014a, 114). Thus teleology works as a heuristic device that guides conduct in two senses. First, it guides inquiry to discover laws of nature, and, second, it guides our moral conduct so that morality and human freedom can be realized within nature (Guyer 2005, 326-7, 9-31). Finally, our inquiry into the laws of nature can also work to assign responsibility for hardships and to adjust our conduct appropriately to remedy them $(C o B, 231,8: 120-121)$.

\section{A TYPOLOGY OF ANTAGONISM}

The previous section establishes that equilibrium is a core condition for antagonism to work indirectly toward progress. Moreover, it shows how determinative and reflective arguments interact in the third definitive article. This discussion already hints at the fact that from a moral standpoint, Kant condemns both European war and colonial conflict. In contrast, according to reflective criteria, and unlike intra-European conflict taking place in Europe, he finds that colonial conflict does not indirectly serve moral advancement. This means that Kant needs to update his claims about antagonism in Perpetual Peace, which he does-as I explain below-by differentiating between (a) intraEuropean conflict in Europe; (b) intra-European conflict in or about the colonies; and (c) conflict between European and colonial peoples. ${ }^{13}$

\section{War and Europe}

Kant holds Europe responsible for the unending conflict in the colonies, and differentiates this conflict from conventional intra-European war. This is already discernible in the Third Critique's contrasting accounts of violent conflict. Here, Kant blames "man's own absurd natural predispositions" for getting himself in trouble and "[making him] put down others of his own species in great misery through oppressive domination [and] barbaric wars" that work "for the destruction of his own species" (CoJ, 318, 5:430, my emphasis). Only a couple of pages later, however, Kant describes war as "an unintentional human endeavor (incited by our unbridled passions)" but also "a deeply hidden and perhaps intentional endeavor of the supreme wisdom, if not to establish, then at least to prepare the way

\footnotetext{
13 Sankar Muthu proposes a binary distinction between resistance that seeks to achieve "equal worth" and "domineering unsocial sociability," where only the former involves productive resistance that benefits societies and cultivates capacities (2014, 93-4), while the latter despotically asserts superiority. There are affinities between my distinction and Muthu's, but I argue that the first kind of resistance depends on a pre-existing equilibrium of forces and that the distinction only emerges in Perpetual Peace, where Kant considers colonial conflict for the first time.
} 
for lawfulness along with the freedom of states, and thereby for a unified system ... with a moral basis" (320, 5:433).

Thus, while the "barbaric wars" referenced in the first passage may end in destruction, the conflict mentioned in the second passage remains the way of nature to develop man's aptitudes, keeping him away from "absurd predispositions" associated with passion and move toward the regulation of states' unlawful freedom (CoJ, 320, 5:432). While destructive wars bring "oppressive domination" and barbarism, other wars are a hidden endeavor of supreme wisdom. No states are mentioned in the first excerpt, suggesting that Kant may be thinking of colonial conflict, while the second extract specifies states, suggesting that war among European states is preparatory for a lawful constitution. ${ }^{14}$ Lest we expect "barbaric wars" to be indirectly conducive to peace, Kant notes after the first passage that nature's beneficence is insufficient to counter these predispositions. Instead, man must overcome them through skill and discipline because he is "the only being on earth that has understanding and hence an ability to set himself purposes of his own choice." While man's vocation is to be "the ultimate purpose of nature," he still "must have the understanding and the will to give both nature and himself reference to a purpose ... independent of nature, self-sufficient, and a final purpose" outside nature (CoJ, 318, 5:431).

Thus, understanding and man's ability to set himself purposes are now central to Kant's notion of progress in the sense that certain forms of antagonism observed in nature need to be criticized publicly and ultimately avoided outright for progress to ensue. These are the wars that result from man's "absurd natural predispositions," not those that constitute "antagonism in accordance with principles of outer freedom," which can be conducive to lawfulness (MoM, 485, 6:347). Rather than an overall shift in his evaluation of antagonism in historical progress, Kant's departure from Idea is a refined understanding of antagonism that distinguishes between different forms of conflict in terms of their indirect teleological role.

Kant's view of war is also concerned with its effects over character. This appears in the first part of Critique of Judgment, when Kant asserts that there is something sublime in war when "it is carried on in an orderly way" and it respects "the sanctity of the citizens' rights." $\mathrm{He}$ claims that the "way of thinking of a people that carries [war] on" is as sublime as the dangers that they face and the courage they show, vis-à-vis the "selfishness, cowardice, and softness" of the commercial spirit of peacetime (122, 5:263). If the honor and courage that Kant associates with certain wars is particularly attuned to awakening the skills and discipline required for men to devise and follow through self-imposed purposes, the excessive violence associated with colonial wars

\footnotetext{
14 These examples are offered in the context of a discussion of human happiness in relation to nature's ultimate end and morality's final end (CoJ, 317-320, 5:429-433; Guyer 2005, 316-35). This discussion is part of the conceptualization of Kant's novel understanding of teleology and the place for different forms of antagonism within it.
}

may be too unbridled and prone to produce the wrong kind of effect.

If we connect these reflections to the historical and textual evidence from previous sections, it is evident that the two dimensions of colonialism highlighted in Kant's assessment (the quest for expansionism and its brutality) have no affinity with progress toward peace. This is because progress requires a virtuous process of friction among equals that will develop men's predispositions. Similarly, while some forms of conflict activate men's courage and drive for honor and advance culture, others awaken their basest passions for evil, making men unfit for citizenship and states unfit to qualify as "a person in the relation of states" (MoM, 485, 6:347). The Drafts confirm this: colonial wars upset the progression toward peace fueled by civilized war among Europeans by-among other things-accelerating wars rather than resulting in the gradual abandonment of aggression, and by facilitating the expansionism of states that "recognize no limitation to their presumptions except whatever their own powerlessness prevents them from doing" treating "the person of the foreigner" as nature-given booty (DPP, 221-222, 23:173). Kant's concern with expansionism is such that "the menacing increase in another state's power" is one of the few grounds he takes to be legitimate, in the state of nature, to initiate war (MoM, 484, 6:346). ${ }^{15}$ Of equal concern to Kant is the multiplicative character of conflict in the colonies. Kant believes the unbridled character of colonial conflict will haunt Europe by fueling more war in Europe. Below I substantiate this claim and also provide insight into two connected conceptual issues: his reconsideration of trade as potentially destructive and the connection between his anti-colonialism and his hierarchical understanding of the world.

\section{Multiplication and Trade}

The multiplicative character of colonial conflict is a core complaint of Kant in the Drafts, where he notes that Europe's position "in reciprocal trade" means that gains or losses from around the world "are ... felt very sensitively in Europe, which receives new and never diminishing material to expand and perpetuate this continent through war rather than peace" (DPP, 23:174, my emphasis). Thus, Kant comes to see trade as a negative force in the quest for European progress. Compare this with his assessment of trade as "another mechanism that unwittingly contributes to the plan of nature" in Idea, where Kant still believes that trade interests will force states "by their own insecurity" to arbitrate and prepare the way for an institution that will arbitrate in the future (IUH, 51, 8:28). The reversal may have to do with Kant's consideration of the actual shape of colonial "trade." In Perpetual Peace, he asserts that European trading posts were excuses for the subjugation of natives. Most "trade," at least in Asia in the 18th century, was conducted by state-chartered

\footnotetext{
15 In the Metaphysics of Morals, he terms this "a right to equilibrium" [Recht des Gleichgewichts] (MoM, 484, 6:346, amended translation).
} 
corporations that recruited armies and had quasisovereignty over territory. In the case of the British East India Company-which was dominant in Asia by 1778 vis-à-vis the Dutch and French companiestrading interests took its army well beyond the confines of East India and into commercially strategic regions, often alongside the British army (Bowen 2005, 45-7). The slave trade was also conducted by trading companies (in the case of Britain, the Royal African and the South Sea companies), which operated in West Africa, typically without territorial control (Morgan 2007, 53$60)$. The close connection between war and trade in trading companies underlies another mechanism of conflict multiplication: the accumulation of sea power and sailors/soldiers that result from the growing trade operations of these companies. As Kant notes: trading companies in the Caribbean train "sailors for warships and so, in turn, carrying on wars in Europe" (TPP, 330, 8:359; DPP, 23:175).

Another example of this phenomenon appears in the Second Definitive Article on international Right, where he argues that "the difference between the European and the American savages" is that the latter eat their enemies, while the former "know how to make better use of [the] defeated ... and would rather increase the number of their subjects," and use them as instruments for more extensive wars (TPP, 326, 8:355). This excerpt is significant because it is the only mention of non-European peoples in the section on international Right, thus identifying the problems emanating from engagements in colonial areas in otherwise virtuous intra-European antagonism.

\section{Multiplication and Hierarchy}

Drafts also problematizes the multiplicative effect of overseas conflict without, however, abandoning his assessment of Europe as superior. For example, Kant notes that "overstepping the borders of hospitality" brings ills to the human species but also to Europe, which originally brought this commerce to all people of the earth, "under the tutelage of [its] most active part." That Europe "finally brought upon itself" the wars it waged upon others, which, "with the awakening of commerce" may become "more and more frequent and to follow faster upon one another" (23:173-4, my emphasis). This passage's reference to "the tutelage of the most active part of the earth" echoes another in Conflict, which Kant also wrote in 1795 . There he argues - in the context of calling human beings "a trifle" vis-à-vis omnipotent nature - that the "sovereigns of [human beings'] own species" treat man as such a trifle by "burdening him as an animal, regarding him as a mere tool ..., or exposing him" in their internal conflicts to have him massacred. This is no trifle, he concludes, but a subversion of the final end of creation itself (305, 7:89, my emphasis). ${ }^{16}$

\footnotetext{
16 This excerpt does not explicitly mention colonial conflict but its wording echoes the discussion of the effects of intra-European conflict in the colonies over natives in Perpetual Peace and the Drafts (DPP , 23:174; TPP , 329, 8:359).
}

Colonial violence is evaluated as purposeless in the scheme of moral progress, "self-inflicted evil" that must be overcome (CoJ, 318-320, 5:431-432; OCS, $301,7: 84) ;{ }^{17}$ it provides endless grounds to perpetuate war-rather than peace-in Europe, magnifying the repercussions in Europe of conflict taking place elsewhere. Again, the Drafts provide illustration, noting that "a spark of violation of human rights suffered in another continent," given the flammability of the thirst for power in human nature, and particularly its leaders, "lights the flame of war that reaches the region where it [originated]" (DPP, 223, 23:175, my emphasis).

The excerpts above are concerned with the backlash of colonial conflict on Europe, and are continuous with four other statements in the Drafts, which claim that Europe has not only waged war upon others but has "finally brought it upon itself" (222, 23:173-174); that "trade in negroes," an offense against black peoples' hospitality, will be "even worse for Europe in its consequences;" that the internal wars Europeans provoked finally reached their own territory (222, 23:174); and that Europe's position in reciprocal trade means it receives new and never diminishing material that expands and perpetuates war in Europe (223, 23:174). This concern makes sense of Kant's understanding of the cosmopolitan realm as a "supplement" [Ergänzung] of the other two realms. The acceleration and never-ending material for conflict that results from colonial conflict means that rightful regulations at the domestic and international (European) level are insufficient to appease the "thirst for power" and regulate the unconventional actors that appear in this period, needing to be complemented by cosmopolitan regulations. This means that Kant's scathing critique of colonialism in 1795 is necessary for the coherence of his project of perpetual peace and this-interpretivelypartly explains the treatment of colonial conflict in Perpetual Peace.

This supplementation is particularly necessary when we read Kant's colonial critique alongside his support for a republican constitution (theoretically, in Perpetual Peace, and politically, in his support for the French Revolution). Through the examples, Kant highlights wars that pit Britain against the nascent Republics in the United States and France, ${ }^{18}$ noting how the steps toward the establishment of rightful civil constitutions were entangled in colonial conflict that impaired their projects, and opposing actions that hinder a society from "providing itself with a civil constitution, which appears good to the people themselves," in a statement that condemns the Revolutionary Wars directly $(C o F, 302,7: 86)$. Kant also considered war detrimental to the pursuit of civic education and other valuable domestic projects characteristic of a republican constitution - by nature the least bellicose-dampening the

\footnotetext{
17 This condemnation, however, seems compatible with the hierarchy evident in the assertion that European states are "the sovereigns" or "the most active part" of the species, a question I discuss at greater length below.

18 On Kant's sympathy for these revolutions, see Lewis Beck (1971) and Ypi (2014b).
} 
development of the culture and institutions that would otherwise work toward peace, making conflict indirectly multiplicative (TPP , 323, 335, 8:350, 365; $C o F$, 304, 7:88).

\section{Sense and Sensibility}

So far, I have argued that Kant differentiated between intra-European conflict - which was indirectly virtuous $^{19}$ - and intra-European conflict taking place in the colonies - which led to expansionism and multiplied conflict in Europe. Kant also singled out conflict between European states and native peoples for the particularly debased practices of European armies. His critique of the cruelty and evil on display, however, is at least partly focused on how they reflect on Europeans' characters and their implications for the progress toward enlightenment he expected.

Some evidence of Kant's concern with war conduct appears in the preliminary articles, which proscribe "dishonorable stratagems" including the use of assassins or poisoners, which corrupt the morals of those who perform them and make them unfit for citizenship (MoM, 485, 6:347). I believe that this same principle is behind Kant's concern with the barbaric practices prevalent in colonial conflict, as expressed in the passage on the Sugar Islands which focuses on "the cruelest [allergrausamste] and most calculated slavery" (TPP, 330, 8:359). Elsewhere in Perpetual Peace, Kant comments on other manifestations of evil in the East Indies where soldiers arrived with the excuse of setting up trading posts but instead "oppress[ed] the inhabitants, incite[d] ... Indian states to widespread wars, famine, rebellions, treachery, and the whole litany of evils [Übel] that oppress the human race" $(329,8: 358$ 359 , amended translation).

Unlike Kant's discussions of asocial sociability, these excerpts are not coupled with reflections on how conflict between evil-regardless of the will of actorswill result in the eventual establishment of a common law and/or peace. Neither does Kant pursue his idea that "the history of freedom begins with evil" ( $C o B$, 227, 8:115; OCS, 308-309, 8:312). Instead, I argue that Kant's concern about the excessive cruelty at play in colonial conflict emerges partly from his assessment of cruel acts as deviations from the economy of feeling he expects to result in the cultivation of humanity and progress toward culture. This process requires making "headway against the crudeness and vehemence of ... inclinations that belong to us primarily as animals" that may not make man "morally [sittlich] better for [life] in society, but still civilized [gesittet] for it" and prepared "for a sovereignty in which reason alone" dominates (CoJ, 321, 5:433).

\footnotetext{
${ }^{19}$ Note that this does not mean that Kant believes remaining in the state of nature is acceptable for European states. Instead, it means that intra-European conflict, if allowed to continue in the state of nature, and as long as the contending powers are relatively equal, is bound to subside eventually and lead the warring parties toward gradual agreement to enter a civil condition (i.e., a federation). This logic degenerates when European states also compete for colonies in a way that multiplies conflict.
}

\section{Antagonism, Judgment, and Teleology}

In sum, the indirect virtuosity of conflict depends on certain equality among the contending forces, which holds within Europe but is threatened by the unbridled expansionism facilitated by the space of the colonies. Among the three forms of antagonism that Kant conceptualizes (intra-European conflict in Europe, intraEuropean conflict in the colonies, and conflict between Europeans and native peoples in the colonies), only the first kind of conflict is consistently considered indirectly conducive to progress.

Kant might have seen violent conflict in the colonies and the cruelty involved in conquest as eroding trust in the plausibility of progress toward peace and morality and undermining men's beliefs in and actions toward such a project, because the "mixture of good and evil in [man's] predisposition" makes it difficult for humankind to assess the possibility of moral progress for the whole species (CoF, 300-301, 7:84). Thus, Kant's intervention offers the right standpoint to assess this question and answer it affirmatively: that "the human race has always been in progress toward the better and will continue to be" (CoF, 304, 7:89) and what could be "an accelerated fall into baseness" is surmountable because of the capacity of human beings to use reason and act freely.

The question of motivation looms large in Kant's public philosophy. He argues that actors' motivation is strengthened particularly by the "feeling of selfinflicted evil, when things disintegrate altogether" which leads them to make things "even better than they were before that state" (CoF, 300, 7:83). While research on the role of history and experience on Kant's theory of progress has focused on the French Revolution as an occurrence that demonstrates humanity's moral tendency (Nicholson 1992; Ypi 2014b), evil acts must also be put in the proper perspective to avoid finding human affairs senseless and turn away in revulsion and despair (CoF, 300, 7:83, IUH, 53, 8:30). Kant is interested in devising the right position from which to regard the course of human affairs and predict the outcome of free actions (CoF, 300, 7:83-84), including evil acts. Given his belief in progress, this position must be one that reflectively points to the surmountability of evil and traces how human actions and institutions can contribute to overcoming them so that acting morally remains motivationally sound.

\section{NOT PHILANTHROPY, BUT RIGHT}

I have so far established that the consequences of colonial conflict on the possibility of European peace and the character of Europeans fueled Kant's critique of colonialism in Perpetual Peace. However, I have not yet considered two connected questions: first, what is the relation between Kant's teleological consideration of colonial conflict and the arguments of Right he makes in Perpetual Peace?, and second, what is the link between Kant's (moral) condemnation of colonial conflict and his race beliefs? 
Perpetual Peace and the Metaphysics of Morals take the steps of: (a) characterizing a realm of interaction that was novel and analytically distinct (including relations that had been an afterthought in Idea) and its connection with other realms and the trajectory toward peace; and (b) condemning morally the annexation of non-European territory. The reconstruction of the first task in Perpetual Peace constitutes this article's core. In Perpetual Peace, Kant deals with cosmopolitanism as a separate realm for the first time. Therefore, it can be expected that his reflections were still rough and only systematized later in The Metaphysics of Morals. In view of the events he witnessed, Kant needed to regulate the barbarism of unconventional warfare in the colonies he identifies in Critique of Judgment and describes forcefully in Perpetual Peace, yet he could not embed cosmopolitan regulations within international Right, which, as noted above, did not include relations with non-states or non-European states.

Regarding the task of defining the moral status of European actions outside of Europe, Kant announces at the outset that Perpetual Peace is concerned with "Right," rather than philanthropy. Following this statement, as noted above, Kant characterizes the actions of Europeans outside of Europe as "cruel" (slavery in the West Indies), displaying "injustice" (their visits/conquests), and "oppression" (in the West Indies) and resulting in "the whole litany of evils that oppress the human race" (i.e., the incitement of Indian states to wars, famine, and rebellions). These condemnations focus on violations of the right of hospitality and on actions that follow from this violation (i.e., the cruelty of slavery in the West Indies and the oppression of East Indian natives and states driven to internal wars).

A look at the Metaphysics of Morals reveals that these two tasks are accomplished differently. On the one hand, the section on cosmopolitanism ( $\$ 62)$ is narrowly concerned with establishing the injustice of settlements in non-European lands (this time specifying the protection of nomadic peoples and using only the examples of the "Hottentots," the Tungusi, and "most of the American Indian nations"). ${ }^{20}$ In this section, Kant rejects "specious reasons" offered for settlement/conquest and claims that they "cannot wash away the stain of injustice" of the forceful means used (490, 6:353).

The destabilizing effect resulting from expansionism and unending colonial conflict, on the other hand, is covered in the section on the right of nations, which theorizes rightful antagonism. In this section, Kant defines: (a) a "right to equilibrium" [Recht des Gleichgewichts] among contiguous states; (b) a principle of outer freedom that allows the preservation of states' belongings but not new (and threatening) acquisitions; (c) conduct of war that is outlawed, like means that would make subjects unfit for citizenship, states unfit for entering relations with other states, or any other conduct that would destroy trust requisite to achieve future peace (MoM, 484-485, 6: 346-347). These statements

${ }^{20}$ When discussing property rights, he adds "the inhabitants of New are in line with Perpetual Peace in condemning conduct incompatible with equal freedom, convergence, and equilibrium, namely, those actions that reveal "a maxim by which, if it were made a universal rule, any condition of peace among nations would be impossible and a state of nature perpetuated" (MoM, 487, 6:349).

Kant's condemnation of settlement in the Metaphysics of Morals is clear and contains substantive innovations vis-à-vis his less systematic pre-1790 reflections on colonialism, which were associated with his writings on racial and civilizational inferiority and, it should be noted, never went as far as authorizing violent conquest and oppression of natives. In particular, non-Europeans are recognized as contracting agents, with a right to exclude, whose nomadic lifestyle establishes possession. Yet it is important to note that Kant's condemnation focuses on the means. ${ }^{21}$ This is not to say that the protection of natives is indirect but to say that these condemnations are compatible with civilizational hierarchy, that is, Kant's belief that populating these countries with civilized peoples would potentially be more conducive to progress, even if he knows that, in the particular juncture when he is writing, this cannot happen without violence, and is thus impermissible. In the section on property rights $(\S 15)$, he concludes that a "veil of injustice" "would sanction any means to a good end" (418, 6:266). The same rationale informs the closing argument of $\S 62$, which claims that "supposedly good intentions cannot wash away the stain of injustice in the means used for them" $(490,6: 353)$. While Kant is skeptical of the intentions being genuinely good, his language is clear in attributing the injustice to the means. He concludes this paragraph by comparing these claims to the arguments that revolutionaries use to justify force, that is, that a more just system can be established. We know of course that Kant favored the kinds of governments that revolutionaries wished to establish, but opposed the means to their establishment, and his arguments against colonial settlement seem to contain a parallel claim.

Claims about civilizational hierarchy are connected to claims of racial hierarchy in Kant's system, since only certain races develop the proper predispositions to attain culture and develop morally (Larrimore 2008). Moreover, the establishment of a unified system of Right is in line with Kant's longstanding concern with achieving unity in multiplicity, in which race played a central role. Thus, Kant's unified system of Right, rather than implying the abandonment of beliefs about hierarchy and difference, could have followed from his postulate of unity in difference - "first an article of moral faith, and then a project for human beings" (Larrimore 2008, 348, 56). In fact, it is the difference

\footnotetext{
${ }^{21}$ Muthu's work focuses on this very point but argues that Kant's anti-paternalism, which understands different cultures as incommensurable, precludes a "duty to civilize others" and thus condemns also the ends $(2000,25$, n, 40). As Inder Marwah notes, however, Kant values culture because of its role as a "transitory move" that pushes humanity toward the perfection of moral capacities, an end that preserves inequality because it privileges European culture which "prepare[s] [humanity] for a sovereignty in which reason alone is to dominate" (CoJ, 321 5:433; Marwah 2012, 386-7).
} 
(i.e., relative weakness) of non-European peoples that requires these protections, because it prevents an engagement in conditions of equality with Europeans, thus making the logic of antagonism - which regulates European states' relations - fail. In other words, protections of Right are extended in order to prevent violence and oppression, but also to accommodate inequality, rather than as a recognition of equality. Thus, in contrast to Mark Larrimore's (1999) claim that Kant considered non-Europeans inferior and meaningless in the grand scheme of progress, I argue that Kant likely came to consider them far from meaningless, and perhaps even a central obstacle to progress toward peace, due to their inability to stand up in "lively competition" against European conquerors.

We can think of this form of incorporation in parallel to that of women, who, as feminist critics of Kant have noted, Kant considers naturally inferior to men and unfit for the public sphere, even while he accords them respect and a role in men's education (Kleingeld 1993; Kofman 1997). ${ }^{22}$ Just as a belief in gender inequality is compatible with a concern with the well-being and general standing of women, incorporating non-Europeans into Kant's system of Right did not require an incorporation in equal terms (Bernasconi 2011, 292), that is, a retreat from Kant's commitments to racial hierarchy. Differently put, condemning violence against non-European groups and the violent means of conquest does not in and of itself require an acceptance of those groups as racially equal or their civilization as comparable to Europe's. The permanence of Kant's racial and civilizational thinking receives support from a later claim, from the 1798 edition of his anthropology lectures:

This much we can judge with probability: that the mixture of stems [Stämme] (by extensive conquests), which gradually extinguishes their characters, is not beneficial to the human race-all so-called philanthropy notwithstanding $(A P P V, 415,7: 320)$.

\section{CONCLUSION}

Examining the historical context of the non-European locales that appear in the third article suggests that, for Kant, a leading concern was the detrimental effect of colonial conflict (both intra-European and between Europe and native peoples) on the progress of Europe toward culture and civilization. Kant's examples suggest that his critique is directed at Britain, the dominant empire, slave trader, and naval power, and the historical rival of France. Kant's ability to communicate this was complicated by the close ties between the Prussian rulers and the House of Hanover and the wartime atmosphere. Kant's intervention can be understood as a plea to European monarchs to retreat from their colonial entanglements and allow for France's repub-

\footnotetext{
${ }^{22}$ There is disagreement in this literature; some commentators claim that Kant's views on women do not impact his moral ideals or that other places in Kant's works grant women rational moral agency (Mikkola 2011; Varden 2015).
}

lican constitution to progress and lead Europe toward peace.

Kant's reflective engagement with experience with the goal of orienting actions toward moral progress works not only positively (through spectators' enthusiasm for revolutions in France and North America) but also negatively (through disgust at the cruelty and spiraling violence). This critical engagement depends on Kant's reconsideration of the value of antagonism vis-à-vis European civilization and moral progress. He finds that two outcomes of colonial conflict, that is, expansionism and the engagement of Europeans in evil acts of cruelty, affect intra-European equilibrium and the development of character among Europeans, respectively. Thus, war is no longer considered to be indirectly conducive to progress, as it had been before. Rather, only conflict among European states in Europe remains indirectly virtuous. Colonial conflict in which Europeans fight other Europeans in the colonies, or do so with the help of mercenaries and trading companies, leads to expansionism and/or the erosion of trust, and ultimately multiplies conflict. Finally, conflict between Europeans and colonial peoples is excessively violent, and pernicious for the character of Europeans. Thus Kant's anti-colonialism in Perpetual Peace contributes to furthering the realizability of domestic and intrastate rightful goals, and formally, but incipiently, codifies a new realm of Right to protect non-Europeans. These protections do not imply a retreat from racial and civilizational hierarchies, but simply a codification of his position on violent conquest and forced settlement, never before specified systematically. In other words, Kant goes beyond his reflective concerns by expressing moral disgust at the violence inflicted on Europeans, a position that is compatible with commitments to racial and civilizational hierarchy. Other scholars concur with Kant's dual investment in European superiority and the immorality of colonial violence, but see the latter as necessary for "the dialectic of progress," where nature combats unsociability with unsociability (McCarthy 2009, 61-2; Tully 2008, 147). Instead, I show that Kant came to see colonial conflict as detrimental to progress and an obstacle to its realizability. His reaction is to tightly regulate the relations of Europeans and nonEuropeans through the concept of hospitality, in the hope of preventing European warfare from expanding into the vast territory outside of Europe. These findings suggest that more research is needed to reconsider the place of Kant's anti-colonial thought in relation to his contemporaries, including Adam Smith and Edmund Burke, among others (Ahmed 2002; Murray 2007; Pitts 2005, 2015; Rothschild 2012).

More broadly, my approach suggests that the context of warfare, politics, and economics that framed the writings of European canonical thinkers is incomplete without considering imperialism. Insular readings of these thinkers (for exceptions see Arneil 1996; BuckMorss 2000; Moloney 2011) may have to do with the scarce acquaintance and engagement of continental thinkers with postcolonial and critical theories, which highlight the centrality of slavery and colonialism to modernity (Mills 1997; Said 1993; Spivak 1999), but also 
the predominant attention of intellectual historians to linguistic-discursive context of texts, rather than the social and political world that informs their theoretical claims (Moyn 2016). This lack of engagement is not only detrimental to the critical inclination of continental scholarship but also of its capacity to accurately interpret thinkers who understood European political economy as intimately connected with colonialism.

The prevailing narrow reading of Kant may be explained by his role in contemporary cosmopolitanism, which may prompt a redemptive reading of his anticolonialism. This "retrospective significance" (Skinner 2002, 72-3) might lead scholars to understand Kant's text to be saying something that he $-\mathrm{I}$ argue-could not have accepted as a fair account of what he was doing (Skinner 2002, Chapter 4). Moreover, the central role of Kant in contemporary cosmopolitan projects should instead make us especially mindful of blind spots in our interpretation in order to avoid transferring Eurocentric and hierarchical notions to our contemporary thinking. For example, it should be noted that Kant's framework, uncorrected, is insufficient to normatively counter racialized narratives of civilization that he helped construct and whose legacies still mark the international sphere (Anghie 2006), although his resources may be creatively used to address the question (Ajei and Flikschuh 2014). Moreover, Kant's idea of a world federation was devised for a group of relatively equal actors, putting in question its suitability to structure contemporary multilateral organizations. Absent the engagement of this scholarship with anti-colonial intellectuals who critically engaged these institutions during the post-Second World War (Du Bois 1945; Wilder 2015), their ability to conceptualize normative critiques of these organizations might be weakened. Incorporating these writings would, moreover, extend the cosmopolitanism of this scholarship from its subject matter to its mode of inquiry, by productively historicizing and denaturalizing some of its conventions (Godrej 2011, 38).

\section{REFERENCES}

Ahmed, Siraj. 2002. "The Theater of the Civilized Self: Edmund Burke and the East India Trials." Representations 78 (1): $28-55$.

Ajei, Martin, and Katrin Flikschuh. 2014. "Colonial Mentality: Kant's Hospitality Then and Now." In Kant and Colonialism, eds. K. Flikschuh and L. Ypi. Oxford: Oxford University Press.

Anghie, , Antony. 2006. "The Evolution of International Law: Colonial and Postcolonial Realities." Third World Quarterly 27 (5): 739-53.

Arneil, Barbara. 1996. John Locke and America. Oxford: Oxford University Press.

Beck, Lewis W. 1971. "Kant and the Right to Revolution." Journal of the History of Ideas 32 (3): 411-22.

Bell, Duncan. 2016. Reordering the World. Princeton: Princeton University Press.

Bernasconi, Robert. 2001. "Who Invented the Concept of Race? Kant's Role in the Enlightenment Construction of Race." In Race, ed. R. Bernasconi. Oxford: Blackwell Publishers, 11-36.

Bernasconi, , Robert. 2003. "Will the Real Kant Please Stand Up. The Challenge of Enlightenment Racism to the Study of the History of Philosophy." Radical Philosophy 117 (January/February).
Bernasconi, Robert. 2011. "Kant's Third Thoughts on Race." In Reading Kant's Geography, eds. S. Elden and E. Mendieta. New York: SUNY Press, 291-318.

Blanning, Timothy C. W. 1996. The French Revolutionary Wars. London: Arnold.

Bowen, Huw V. 2005. The Business of Empire. Cambridge: Cambridge University Press.

Brown, Gregory Stephen. 2003. Cultures in Conflict: The French Revolution. Westport: Greenwood Publishing.

Buck-Morss, Susan. 2000. "Hegel and Haiti." Critical Inquiry 26 (4): $821-65$.

Cavallar, Georg. 2014. "Kant and the Right of World Citizens: An Historical Interpretation." In Critique of Cosmopolitan Reason, eds. R. Letevall and K. Petrov. Oxford: Peter Lang, 49-75.

Clewis, Robert R. 2015. "Kant's Natural Teleology? The Case of Physical Geography." In Reading Kant's Lectures, ed. R. R. Clewis. Berlin: Walter de Gruyter, 526-52.

Clulow, Adam. 2014. The Company and the Shogun. New York: Columbia University Press.

Du Bois, W. E. B. 1945. Color and Democracy: Colonies and Peace. New York: Harcourt, Brace and Company.

Dubois, Laurent, and John Garrigus. 2006. Slave Revolution in the Caribbean 1789-1804. Boston: Bedford/St. Martins.

Edler, Friedrich. 1911. The Dutch Republic and the American Revolution. Baltimore: The Johns Hopkins Press.

Egnal, Marc, and Joseph A. Ernst. 1972. "An Economic Interpretation of the American Revolution." The William and Mary Quarterly 29 (1): 3-32.

Fremont-Barnes, Gregory. 2001. The French Revolutionary Wars. Oxford: Osprey Publishing.

Furnivall, John S. 2010. Netherlands India. Cambridge: Cambridge University Press.

Gauthier, Florence. 2014. Triomphe et mort de la révolution des droits de l'homme et du citoyen (1789-1795-1802). Paris: Éditions Syllepse.

Geggus, David Patrick. 1982. Slavery, War, and Revolution. Oxford: Clarendon Press.

Godrej, Farah. 2011. Cosmopolitan Political Thought. New York: Oxford University Press.

Guyer, Paul. 2005. Kant's System of Nature and Freedom. New York: Oxford University Press.

Hedrick, Todd. 2008. "Race, Difference, and Anthropology in Kant's Cosmopolitanism." Journal of the History of Philosophy 46 (2): $245-68$.

Hill Jr., Thomas E., and Bernard R. Boxill. 2001. "Kant and Race." In Race and Racism, ed. B. R. Boxill. New York: Oxford University Press.

Kleingeld, Pauline. 1993. "The Problematic Status of GenderNeutral Language in the History of Philosophy: The Case of Kant." The Philosophical Forum 25 (2): 134-50.

Kleingeld, Pauline. 2007. "Kant's Second Thoughts on Race." The Philosophical Quarterly 57 (229): 573-92.

Kleingeld, Pauline. 2012. Kant and Cosmopolitanism. Cambridge: Cambridge University Press.

Kleingeld, Pauline. 2014a. "The Development of Kant's Cosmopolitanism." In Politics and Teleology in Kant, eds. P. Formosa, A. Goldman and T. Patrone. Cardiff: University of Wales Press.

Kleingeld, Pauline. 2014b. "Kant's Second Thoughts on Colonialism." In Kant and Colonialism, ed. K. Flikschuh and L. Ypi. Oxford: Oxford University Press.

Kofman, Sarah. 1997. "The Economy of Respect: Kant and Respect for Women.” In Feminist Interpretations of Immanuel Kant. University Park: The Pennsylvania State University Press.

Krimmer, Elisabeth. 2008. "A Portrait of War, a Grammar of Peace: Goethe, Laukhard, and the Campaign of 1792." German Life and Letters 61 (1): 46-60.

Larrimore, Mark. 1999. "Sublime Waste: Kant on the Destiny of the 'Races'." Canadian Journal of Philosophy 29 (Sup 1): 99-125.

Larrimore, Mark. 2008. "Antinomies of Race: Diversity and Destiny in Kant." Patterns of Prejudice 42 (4-5): 341-63.

Laurence, Keith Ormiston. 1995. Tobago in Wartime, 1793-1815. Kingston: University of West Indies Press.

Louden, Robert B. 1999. Kant's Impure Ethics. New York: Oxford University Press. 
Louis-Philippe. 1974. "Mémoires de Louis-Philippe duc d'Orléans, écrits par lui-même, t. ii." Paris: Plon.

Maliks, Reidar. 2014. Kant's Politics in Context. Oxford: Oxford University Press.

Malleson, George Bruce. 2010. History of the French in India. Cambridge: Cambridge University Press.

Marwah, Inder. 2012. "Bridging Nature and Freedom? Kant, Culture, and Cultivation." Social Theory and Practice 38 (3): 385-406.

McCarthy, Thomas. 2009. Race, Empire, and the Idea of Human Development. Cambridge: Cambridge University Press.

Mikkola, Mari. 2011. "Kant on Moral Agency and Women's Nature." Kantian Review 16 (1): 89-111.

Mills, Charles W. 1997. The Racial Contract. Ithaca: Cornell University Press.

Mills, Charles W. 2005. "Kant's Untermenschen." In Race and Racism in Modern Philosophy, ed. A. Valls. Ithaca: Cornell University Press.

Mills, Charles W. 2014. "Kant and Race, Redux." Graduate Faculty Philosophy Journal 35 (1-2): 125-57.

Mintz, Sidney Wilfred. 1985. Sweetness and Power. New York: Viking.

Moloney, Pat. 2011. "Hobbes, Savagery, and International Anarchy." American Political Science Review 105 (1): 189-204.

Morgan, Kenneth. 2007. Slavery and the British Empire. Oxford: Oxford University Press.

Moyn, Samuel. 2016. "History and Political Theory: A Difficult Reunion." Theory \& Event 19 (1). https://muse.jhu.edu/article/ 607285.

Murray, Julie. 2007. "Company Rules: Burke, Hastings, and the Specter of the Modern Liberal State." Eighteenth-Century Studies 41 (1): 55-69.

Muthu, Sankar. 2000. "Justice and Foreigners: Kant's Cosmopolitan Right." Constellations 7 (1): 23-45.

Muthu, Sankar. 2014. "Productive Resistance in Kant's Political Thought: Domination, Counter-Domination, and Global Unsocial Sociability." In Kant and Colonialism, eds. K. Flikschuh and L. Ypi. Oxford: Oxford University Press.

Nicholson, , Peter P. 1992. "Kant, Revolutions, and History." In Kant's Political Philosophy, ed. H. Lloyd Williams. Chicago: The University of Chicago Press.

Niesen, Peter. 2007. "Colonialism and Hospitality." Politics and Ethics Review 3 (1): 90-108.

Niesen, Peter. 2014. "Restorative Justice in International and Cosmopolitan Law." In Kant and Colonialism, eds. K. Flikschuh and L. Ypi. Oxford: Oxford University Press.

Pagden, , Anthony. 2014. "The Law of Continuity: Conquest and Settlement within the Limits of Kant's International Right." In Kant and Colonialism, eds. K. Flikschuh and L. Ypi. Oxford: Oxford University Press.

Palmer,, R. R. 1954. "Much in Little: The Dutch Revolution of 1795" The Journal of Modern History 26 (1): 15-35.

Pitts, Jennifer. 2005. A Turn to Empire. Princeton: Princeton University Press.

Pitts, Jennifer. 2015. "Irony in Adam Smith's Critical Global History." Political Theory:0090591715588352.
Pradeep, Barua. 2011. "Maritime Trade, Seapower, and the AngloMysore Wars, 1767-1799." The Historian 73 (1): 22-40.

Rawley, James A., and Stephen D. Behrendt. 2005. The Transatlantic Slave Trade. Lincoln: University of Nebraska Press.

Ripstein, Arthur. 2014. "Kant's Juridical Theory of Colonialism." In Kant and Colonialism, eds. K. Flikschuh and L. Ypi. Oxford: Oxford University Press.

Rothschild, , Emma. 2012. "Adam Smith in the British empire." In Empire and Modern Political Thought, ed. S. Muthu. Cambridge: Cambridge University Press, 184-98.

Said, Edward W. 1993. Culture and Imperialism. London: Chatto and Windus.

Shapiro, Stephen. 2008. The Culture and Commerce of the Early American Novel: Reading the Atlantic World-System. University Park: The Pennsylvania State University Press.

Skinner, Quentin. 2002. Visions of Politics. Vol. 1. Cambridge: Cambridge University Press.

Spivak, Gayatri Chakravorty. 1999. A Critique of Postcolonial Reason. Cambridge: Harvard university press.

Storey, Ian. 2015. "Empire and Natural Order in Kant's 'Second Thoughts' on Race." History of Political Thought 26 (4): 670-99.

Tarling, Nicholas. 1958. "The Relationship between British Policies and the Extent of Dutch Power in the Malay Archipelago 1784-1871 " Australian Journal of Politics \& History 4 (2): 179-92.

Tully, James. 2008. Public Philosophy in a New Key. Volume II. Cambridge: Cambridge University Press.

Turner, L. C. F. 1966. "The Cape of Good Hope and Anglo-French rivalry 1778-1796." Historical Studies: Australia and New Zealand $12(46): 166$.

Valdez, Inés. 2012. "Perpetual What? Injury, Sovereignty, and a Cosmopolitan View of Immigration." Political Studies 60 (1): 95-114.

Varden, Helga. 2015. "Kant and Women." Pacific Philosophical Quarterly (Early View): 1-42.

Whitaker, Arthur P. 1936. "Louisiana in the Treaty of Basel." The Journal of Modern History 8 (1): 1-26.

Wilder, Gary. 2015. Freedom Time. Durham: Duke University Press.

Williams, Howard. 2014. "Colonialism in Kant's Political Philosophy." Diametros (39): 154-81.

Wood, Allen W. 1996a. "General Introduction." In Religion and Rational Theology, eds. A. Wood and G. di Giovanni. Cambridge: Cambridge University Press.

Wood, Allen W. 1996b. "Introduction." In Practical Philosophy, ed. M. J. Gregor. Cambridge: Cambridge University Press, 275-76.

Wood, Allen W. 1998. "Kant's Project for Perpetual Peace." In Cosmopolitics, eds. P. Cheah and B. Robbins. Minneapolis: University of Minnesota Press.

Ypi, Lea. 2014a. "Commerce and Colonialism in Kant's Philosophy." In Kant and Colonialism, eds. K. Flikschuh and L. Ypi. Oxford: Oxford University Press.

Ypi, Lea. 2014b. "On Revolution in Kant and Marx." Political Theory 42 (3): 262-87. 